\title{
Geospatial Predictive Modelling for Climate Mapping of Selected Severe Weather Phenomena Over Poland: A Methodological Approach
}

\author{
Ewelina Walawender, ${ }^{1,2}$ Jakub P. Walawender, ${ }^{2,1}$ and Zigigniew Ustrnul ${ }^{2,1}$
}

\begin{abstract}
The main purpose of the study is to introduce methods for mapping the spatial distribution of the occurrence of selected atmospheric phenomena (thunderstorms, fog, glaze and rime) over Poland from 1966 to 2010 (45 years). Limited in situ observations as well the discontinuous and location-dependent nature of these phenomena make traditional interpolation inappropriate. Spatially continuous maps were created with the use of geospatial predictive modelling techniques. For each given phenomenon, an algorithm identifying its favourable meteorological and environmental conditions was created on the basis of observations recorded at 61 weather stations in Poland. Annual frequency maps presenting the probability of a day with a thunderstorm, fog, glaze or rime were created with the use of a modelled, gridded dataset by implementing predefined algorithms. Relevant explanatory variables were derived from NCEP/NCAR reanalysis and downscaled with the use of a Regional Climate Model. The resulting maps of favourable meteorological conditions were found to be valuable and representative on the country scale but at different correlation $(r)$ strength against in situ data (from $r=0.84$ for thunderstorms to $r=0.15$ for fog). A weak correlation between gridded estimates of fog occurrence and observations data indicated the very local nature of this phenomenon. For this reason, additional environmental predictors of fog occurrence were also examined. Topographic parameters derived from the SRTM elevation model and reclassified CORINE Land Cover data were used as the external, explanatory variables for the multiple linear regression kriging used to obtain the final map. The regression model explained $89 \%$ of annual frequency of fog variability in the study area. Regression residuals were interpolated via simple kriging.
\end{abstract}

Key words: Geospatial modelling, severe weather phenomena, regression kriging, climate mapping, Poland.

1 Institute of Geography and Spatial Management, Jagiellonian University, 7 Gronostajowa St., Krakow, Poland. E-mail: ewelina.walawender@doctoral.uj.edu.pl

2 Institute of Meteorology and Water ManagementNational Research Institute, 14 Borowego St., Krakow, Poland.

\section{Introduction}

Severe weather is an extreme meteorological event or phenomenon, which represents a real threat to human life and property (World Meteorological Organization 2004). Weather hazards may occur suddenly and not leave much time for reaction. Furthermore, these occurrences are spatially varied and should be identified by an area. Hence, knowledge about the spatial distribution and strength of dangerous atmospheric phenomena is crucial for reliable local risk assessment as well as effectiveness in preventing and mitigating weather disasters. Some of the most common dangerous weather phenomena that occur over Poland are fog, thunderstorms (lightning and hail) and icing (rime and glaze).

Understanding the spatial variability and intensity of severe weather phenomena makes it possible to determine regional sensitivity to extreme atmospheric hazards at different risk levels. Spatial prediction methods for several weather elements are relatively well recognized and widely described (e.g. HARTKAMP et al. 1999; Chapman and Thornes 2003; Dobesch et al. 2007; Li and Heap 2008; Tveito et al. 2008; SLuiter 2009). The most frequently studied were: air temperature (e.g. NinYEROLA et al. 2000, 2007b; Brown and Comrie 2002; Vicente-Serrano et al. 2003; Ustrnul and CZEKIERda 2005, Benavides et al. 2007; SZYMANOWSKI and KRYZA 2013), solar radiation (e.g. Heuvelink and Griffith 2010; Kryza et al. 2010; RuIZ-Arias et al. 2011; WANG et al. 2014), precipitation (e.g. NinYerola et al. 2000, 2007a; Martínez-Cob 1996; Brown and Comrie 2002; Vicente-Serrano et al. 2003; Wagner et al. 2012; Di PIAZZA et al. 2011), evapotranspiration (e.g. Martínez-Cob 1996; Vicente-Serrano et al. 2007; 
Shirin MANeSh et al. 2013) and snow cover (e.g. López-Moreno and Nogués-Bravo 2005, 2006; LóPEZ Moreno and Vicente-Serrano 2007; Blanchet and LeHNing 2010). Thus far, not much attention has been paid so far to techniques for mapping some visually observed atmospheric phenomena (e.g. fog, dew, hoarfrost, icing, rime, glaze, thunderstorms), which are usually small-scale, often spatially discontinuous, inherently complicated and difficult to predict and/or measure. The volume of source data is also usually too small for interpolation because phenomena are visually observed only at synoptic and research weather stations where a human observer records observations. For spatially continuous mapping of atmospheric phenomena characteristics, estimation based on selected physical relationships is recommended (World Meteorological Organization 2011). This often requires application of predictive modelling and mapping techniques also known as geospatial data mining (YuAn et al. 2005; SHEKHAR et al. 2005) instead of traditional spatial interpolation methods (Berry 2005; Diem and Comrie 2002). In this case, geospatial predictive modelling and mapping techniques were used for estimating the spatial distribution of selected atmospheric phenomena over the area of Poland on the basis of rasterised environmental variables (FrANKLIN 1995).

The main purpose of the study is to present an improved climate mapping method for evaluating the spatial distribution of selected small-scale atmospheric phenomena based on limited input data. Geospatial predictive models of thunderstorms, fog, glaze, and rime were developed to obtain spatially continuous maps. Cartographic versions of similar maps have already been published in the Meteorological hazard atlas of Poland (Ustrnul et al. 2014) where the spatial and temporal variability of each given phenomenon is discussed. In this study, the methodological approach is presented.

\section{Study Area and Data}

\subsection{Weather Observation Data (in Situ Data)}

The study area is Poland, a central European country $\left(313,000 \mathrm{~km}^{2}\right)$ characterized by a transitional climate with both oceanic and continental influences.
Elevation varies from almost $2500 \mathrm{~m}$ above sea level in the Tatra Mountains in the south to $2 \mathrm{~m}$ below sea level in the north. Changing oceanic and continental influences together with complex physiography make weather phenomena in Poland difficult to predict.

Even though advanced measurement methods of weather parameters do exist, there is still an evident shortage of objective and quantitative observational data on atmospheric phenomena. Taking into account weather phenomena such as fog, thunderstorms, glaze, and rime, visual observations performed at weather stations serve as the only available data source for Poland.

However, there are several limitations of in situ observations, which have to be considered:

- Subjectivity of the observations, which depend on the knowledge and experience of the observer,

- The way observations are coded in the SYNOP dispatch; current weather code makes it impossible to obtain information on the intensity of each given phenomenon (no quantifiers available),

- The local nature of atmospheric phenomena strongly depends on the variability of key local environmental conditions, such as topography and land cover.

All such limitations seriously complicate the use of interpolations method for the purpose of creating spatially continuous maps of hazardous atmospheric phenomena. Nevertheless, visual observation data were presented directly in form of graduated symbol maps (Fig. 1) to gain general view on variability of a given phenomenon over the Poland territory and gather an input data to modelling results validation.

Daily observational data for a period of 45 years (1966-2010) were used. Careful verification and homogenisation of the time series was done in accordance with WMO recommendations (World Meteorological Organization 2011) in order to complete the missing values. Finally, daily data on observed thunderstorms, fog, glaze, and rime obtained from 61 weather stations spread across Poland were included in the analysis (Fig. 2a).

For favourable meteorological conditions algorithms construction (see Sect. 3.1) and RegCM modelling validation, data from every $3 \mathrm{~h}$ observations were also used. Additionally, aerological data 

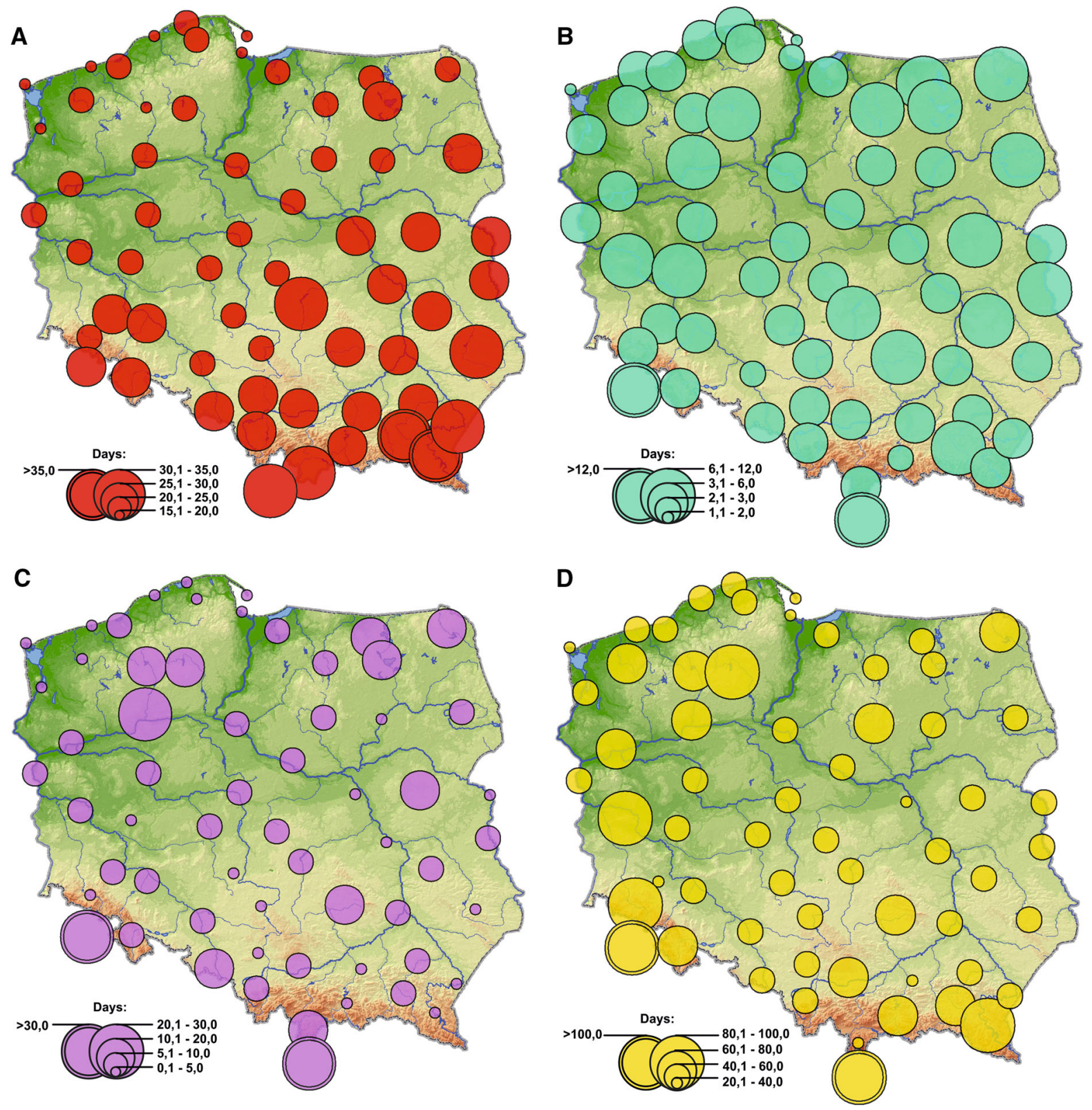

Figure 1

Average annual number of days with thunderstorms (a), glaze (b), rime (c), and fog (d) observed at weather stations

(soundings from 00 UTC and 12 UTC) from three Polish upper-air stations (Łeba, Wrocław, and Legionowo) were derived and used in glaze and thunderstorms algorithm construction and modelling results validation.

All observation data were derived from meteorological stations which work within the national network and were provided by the Institute of
Meteorology and Water Management-National Research Institute.

\subsection{Reanalysis and Regional Climate Model Data}

Due to the lack of objective quantitative data derived from an adequate number of observations, 


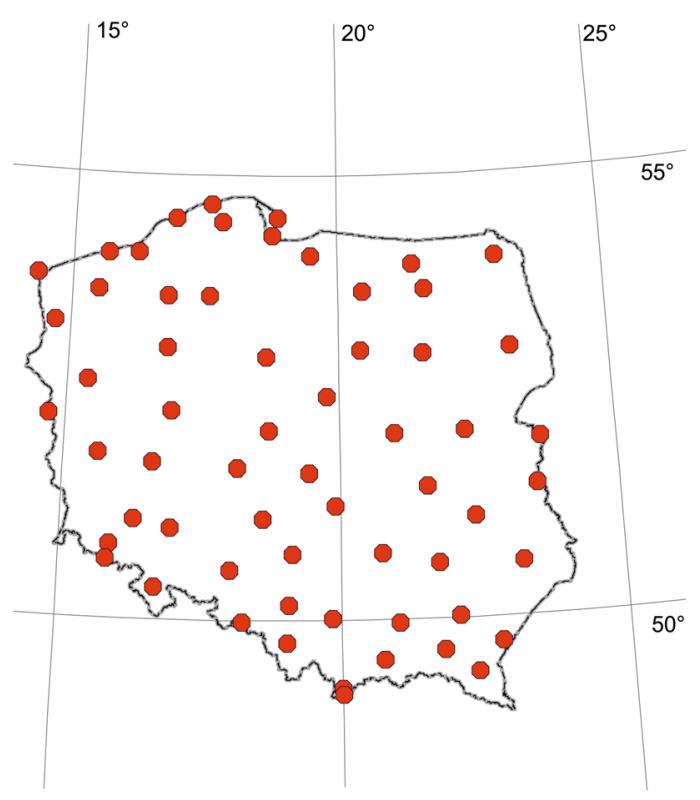

- in-situ weather observations

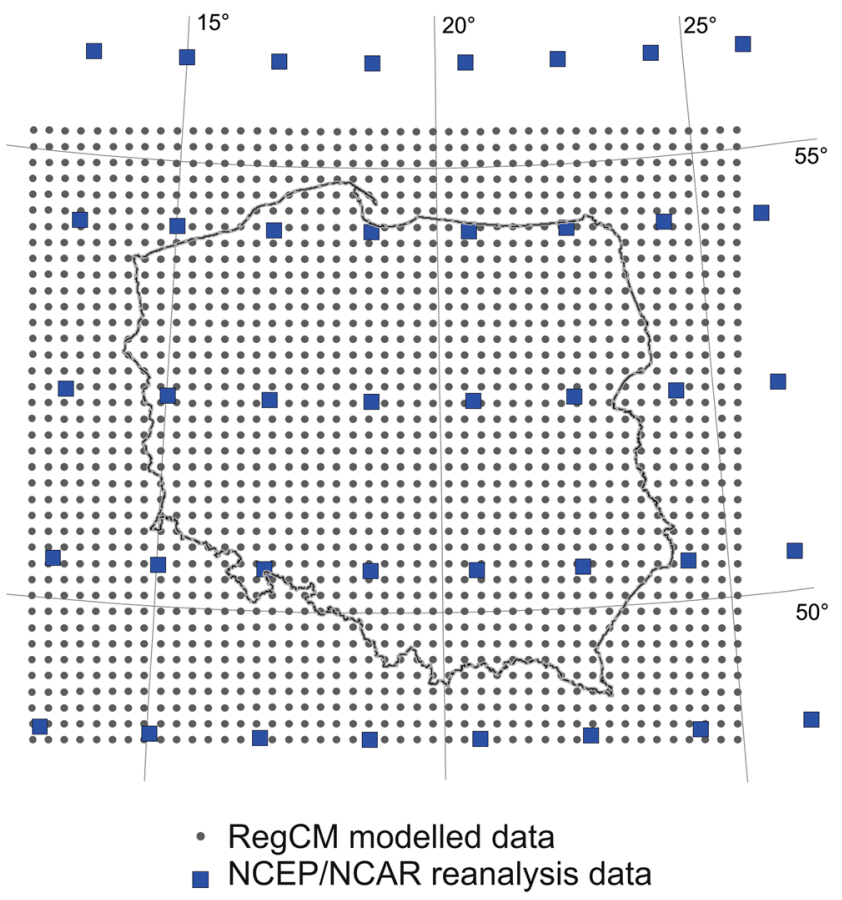

Figure 2

Location of the weather stations used in the study (a) in comparison to NCEP/NCAR reanalysis and RegCM model gridded data (b) additional environmental data were tested for statistical dependence (predictor testing). To obtain regularly-gridded coverage, a 45-year study period (1966-2010) was used with NCEP/NCAR reanalysis data (KALNAY et al. 1996; KISTLER et al. 2001) with 6-h temporal resolution ([1] NCEP 2015). A $2.5 \times 2.5$ decimal degree gridded dataset contained information at the surface level $(2 \mathrm{~m}$ above the ground) and 17 different pressure levels in the atmosphere. It was used as an input for dynamical downscaling (WILBY and WigLEY 1997) carried out with the use of the RegCM model, version 4.1.1. (Elguindi et al. 2011). Thanks to its improved parameters associated with atmospheric physics and land cover patterns, the RegCM regional climate model is suitable for modelling weather conditions on a regional scale (Giorgi and ANyAh 2012). As a result, homogenous gridded datasets for the surface layer $(2 \mathrm{~m})$ and 23 upper atmospheric levels were obtained with a spatial resolution of $20 \mathrm{~km}$ and a temporal resolution of $3 \mathrm{~h}$ (Fig. 2b).

\subsection{Environmental Variables}

Some atmospheric phenomena vary considerably even over a relatively small area. Because of this, valuable data on local meteorological conditions as well as information on several key environmental variables need to be included for proper climate mapping. In this study, fog was the variable most dependent on local environmental characteristics. According to COST Action 722 (Short range forecasting methods of fog, visibility and low clouds, JACOBS et al. 2007), topography and land use (connected also with soil moisture and vegetation) were concerned as the most important predictors. Several auxiliary parameters were extracted from an SRTM Digital Elevation Model v.4.1 (JARVIS et al. 2008) with spatial resolution at $90 \mathrm{~m}$ and from the CORINE Land Cover 2000 vector database (BossARD et al. 2000; [2] EEA Data and Maps 2015) with the smallest mapping unit at 25 hectares. Final maps were generated with a spatial resolution of $250 \mathrm{~m}$, 


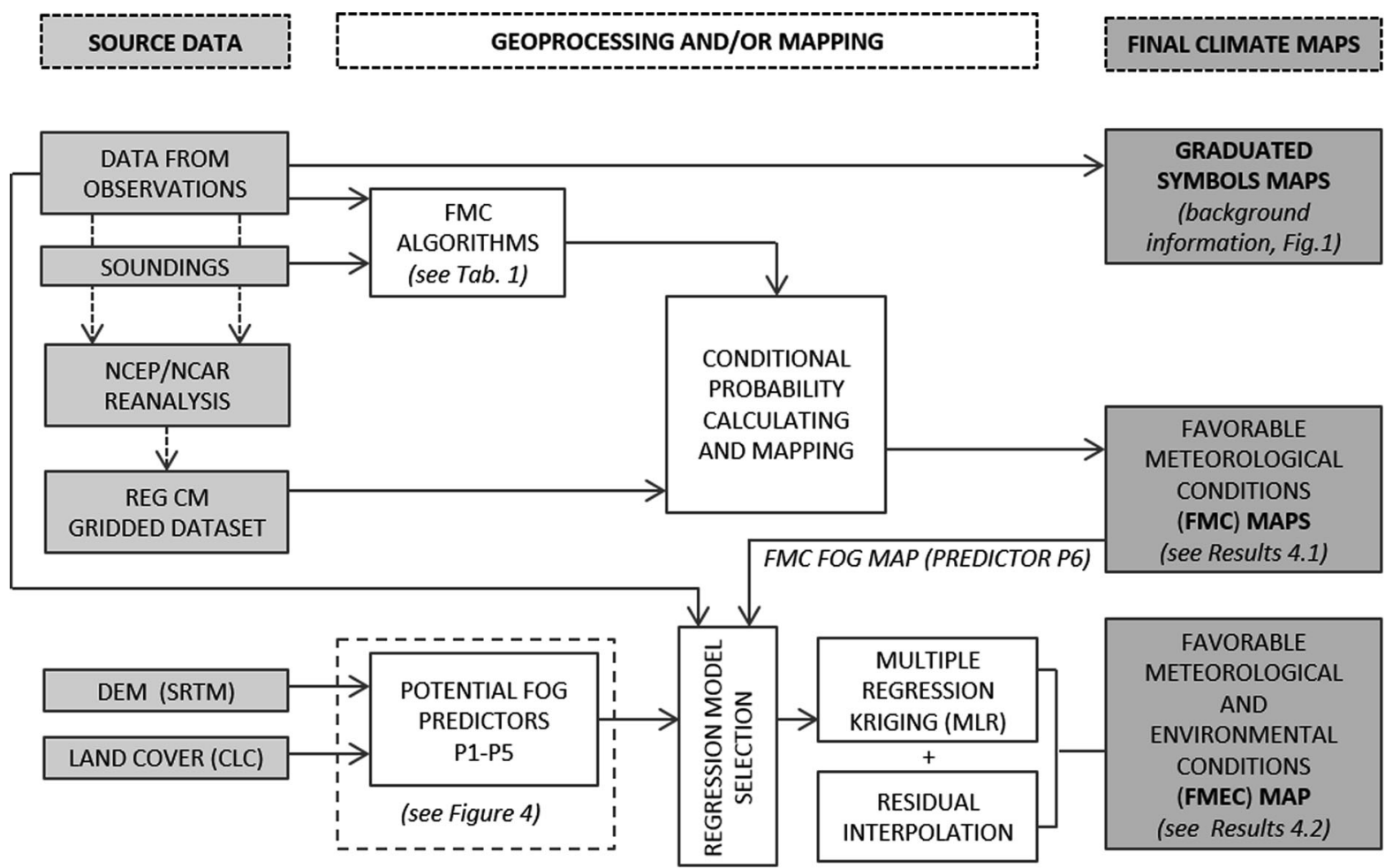

Figure 3

General workflow scheme

which seems to be adequate for climate mapping on the scale of Poland.

\section{Methodology}

Section 3 outlines the methods used for the map generation process, including a proposed approach to discontinuous phenomena mapping.

The whole workflow (Fig. 3) consisted of three steps which were finalised by three different types of climate maps:

1. Direct presentation of in situ observation (graduated symbols maps) (Sect. 2.1).

2. Conditional probability mapping based on favourable meteorological conditions algorithms (FMC maps) (Sects. 3.1 and 4.1).

3. Extending FMC map with environmental predictors employed in multiple linear regression kriging (FMEC map) (Sects. 3.2 and 4.2).

\subsection{Predictive modelling based on favourable meteorological conditions (fmc) algorithms and gridded data}

In order to obtain spatially continuous climate maps of the probability of occurrence of fog, thunderstorms, glaze, and rime an approach based on conditional probability algorithms and predictive modelling was employed. These methods are widely used in weather forecasting (LORENC 1986; KELLER and KUCHERA 2004), but since they are based on the detailed analysis of real data, they can also be successfully applied in climate research (THORNe et al. 2012). The first step consisted of an extended analysis of long-term data from daily and $3 \mathrm{~h}$ weather observations. Favourable meteorological conditions for each phenomenon were determined through an analysis of all measured and observed weather parameters during the occurrence of each studied phenomenon. In the case of thunderstorms and glaze, upper-air soundings were additionally analysed for characteristic patterns. Finally, empirical 
formulas and thresholds were defined for all the selected phenomena. The entire process of algorithm definition was undertaken as a part of a task called "Maps of Meteorological Hazards" which was done within the framework of the EU co-financed project "IT system of the country's protection against extreme hazards" (Polish acronym: ISOK) (WYPYCH et al. 2014; UstRnul et al. 2015). The detailed procedure for the construction and validation of each algorithm is beyond the scope of this paper (an example for thunderstorms can be found in WALAWENDER et al. 2015), which focuses mainly on mapping methods. Simplified versions of favourable weather conditions algorithm for each given phenomenon are shown in Table 1.

Subsequently, algorithms were implemented with the use of RegCM modelled data (1966-2010) (see Sect. 2.2). Finally, the mean annual frequency of favourable conditions was calculated for each of the four studied phenomena. Gridded values were interpolated via an exact method (radial basis functioncompletely regularized spline) to keep the grid point values in the output geostatistical surface.
Validation of obtained RegCM modelling results was performed through implementation of FMC algorithms into available in situ data. Every $3 \mathrm{~h}$ data from weather stations without any missing values were used in the process. Finally, 1966-2010 data from 42 weather station were used for rime and fog FMC modelling validation. Validation of thunderstorms and glaze FMC map (RegCM results) was performed only for three weather-stations (Leba, Legionowo, Wroclaw-as FMC algorithms demanded data from upper-air soundings) using the data from 2003-2010 period because of the very poor upper weather data availability (described in WALAWENDER et al. 2015).

\subsection{Environmental Predictors and Regression Kriging: Fog Map Example}

As the occurrence of fog is usually highly dependent on local environmental conditions, more predictors (apart from certain weather parameters) are needed to explain its spatial variability. The distribution of fog is first of all determined by relief

Table 1

Components of favourable weather conditions algorithms (simplified version)

\begin{tabular}{|c|c|}
\hline & Favorable meteorological conditions \\
\hline Fog & $\begin{array}{l}\text { Visibility as a function of relative humidity } \\
\mathrm{VIS}=800 \times(101-\mathrm{RH}) / \mathrm{RH}^{1.75} \rightarrow \mathrm{VIS}<1.3 \\
P<0.1\end{array}$ \\
\hline Thunderstorms & $\begin{array}{l}\text { Convective available potential energy (CAPE) together with convective precipitation } \\
\text { MUCAPE }>200 \text { (calculated from } 23 \text { isobaric (sigma) levels) } \\
\text { Type of precipitation }\end{array}$ \\
\hline Glaze & $\begin{array}{l}\text { Precipitation, air temperature at } 700,850 \text { and } 925 \mathrm{hPa} \text { isobaric levels }\left({ }^{\circ} \mathrm{C}\right) \text { and near the } \\
\text { surface }(2 \mathrm{~m} \text { and } 5 \mathrm{~cm} \text { above the ground }) \\
\text { T } 700 \mathrm{hPa}<-2 \\
\text { T } 850 \mathrm{hPa}:>-4 \\
\text { T } 925 \mathrm{hPa}:>-6 \\
\text { T } 2 \mathrm{~m}>-6{ }^{\circ} \mathrm{C} \text { and T } 2 \mathrm{~m}<+2 \\
\text { T } 5 \mathrm{~cm}<0 \\
P>0.1\end{array}$ \\
\hline Rime & $\begin{array}{l}\text { Probability of rime as a function of relative humidity and air temperature } 2 \mathrm{~m} \text { a.g.l. } \\
\text { Lack of precipitation (different functions depending on } \mathrm{T} \text { value) } \\
\mathrm{T} 2 \mathrm{~m}<0.1 \\
P<0.1 \\
\mathrm{RH}>0.715 \times \mathrm{T} 2 \mathrm{~m}+94\end{array}$ \\
\hline
\end{tabular}

$V I S$ visibility $(\mathrm{km}), R H$ relative humidity $(\%), P$ precipitation $(\mathrm{mm}), M U C A P E$ Most Unstable CAPE $(\mathrm{J} / \mathrm{kg}), T_{5 \mathrm{~cm}}$ air temperature $5 \mathrm{~cm}$ above the ground $\left({ }^{\circ} \mathrm{C}\right), T_{2 m}$ air temperature $2 \mathrm{~m}$ above the ground $\left({ }^{\circ} \mathrm{C}\right)$ 
and its interactions with the air. There exists a strong and complex relationship between fog occurrence and local topography (elevation and landform) and land cover patterns (e.g. amount of water bodies or green areas). These parameters are crucial for spatial prediction of fog (JACOBS et al. 2007). Predictive mapping makes it possible to integrate both meteorological and geographic data (VICENTE-SERRANO et al. 2010) to estimate the spatial distribution of a given variable.

In this study multiple linear regression (MLR, also known as environmental correlation) with additional residual interpolation (so called Multiple Linear Regression Kriging-MLRK, Hengl et al. 2004; Hengl 2007, 2009) was tested for mapping fog occurrences over the territory of Poland.

Exploratory analysis was carried out first to select an appropriate set of key environmental variables. The locations of all available weather stations were verified with the use of high resolution aerial photographs and orthophotomaps. All improperly assigned XY coordinates were adjusted by geocoding postal addresses. Finally, a location accuracy of $90 \mathrm{~m}$ (consistent with nominal SRTM pixel size) was achieved and made it possible to check relationships between predictors and input data with greater precision and reliability. Selected environmental predictors were converted into raster format. The diagram in Fig. 4 illustrates the process.

Topographic predictors were obtained from SRTM data. Elevation (meters above sea level) (P1) was extracted directly from SRTM data and further used as an input raster to calculate the Topographic Position Index (TPI) (GALlant and WILSON 2000). A dedicated ArcGIS extension developed by JENNESS (2006) was used to calculate TPI on the basis of elevation data. TPI (P2) is an objective semiautomated landform classifier based on neighbourhood analyses. It shows the difference between the elevation in each pixel and the average elevation in its neighbourhood defined by a circle of arbitrary radius which depends on the level of detail assumed in the analysis. In this study, for the resampled $250 \mathrm{~m}$ DEM raster dataset, the radius of 200 cells was defined in order to extract large terrain features that differentiate key regional climate conditions. To obtain the final raster predictor (P2), TPI was recalculated into absolute values as both uplands (TPI $\gg 0$ ) and valleys (TPI $\ll 0$ ) favour the occurrence of fog.

Corine Land Cover (CLC), which was originally created as a vector dataset was transformed to a raster with $250 \mathrm{~m}$ resolution. Urban areas, green (vegetated) areas, as well as wetlands and water bodies were extracted from reclassified CLC data (Table 2).

Regarding conditions of fog occurrence, buffer and focal analyses were applied to obtain the percentage of urban/green/water areas within a $2.5 \mathrm{~km}$ buffer zone around each available weather station and similarly around each CLC raster cell. The analysis was repeated three times in order to compute three raster datasets (three predictors): percentage share of urban areas (P3), percentage share of green areas (P4), and percentage share of wetlands and water bodies (P5). The entire set of predictors (including P6-fog favourable meteorological conditions described in Sect. 2.2) are shown in Table 3.

The selected predictors were examined with stepwise regression analysis to check the spatial relationships between the occurrence of key phenomena and corresponding predictors. The following statistical criteria were taken into account to identify the best fitted Multiple Linear Regression (MLR) model based on the ordinary least squares (OLS) method: adjusted R-squared $\left(\mathrm{Adj}^{2}\right)$, corrected Akaike Information Criterion (AICc), Koenker Statistic $p$ value $(\mathrm{K}(\mathrm{BP}))$ and the Maximum Variance Inflation Factor (MaxVIF). Jarque-Bera (JB) test was performed on model residuals to indicate whether they are normally distributed. Global Moran's I statistic $p$ values (SA) were calculated to decide whether the regression residuals are spatially autocorrelated and further interpolation is required.

The probability of fog favourable meteorological and environmental conditions (FMEC) was calculated using map algebra on predictor raster datasets, applying selected MLR model-MLR output raster dataset. Regression residuals were then interpolated via simple kriging (recommended by HenGL et al. 


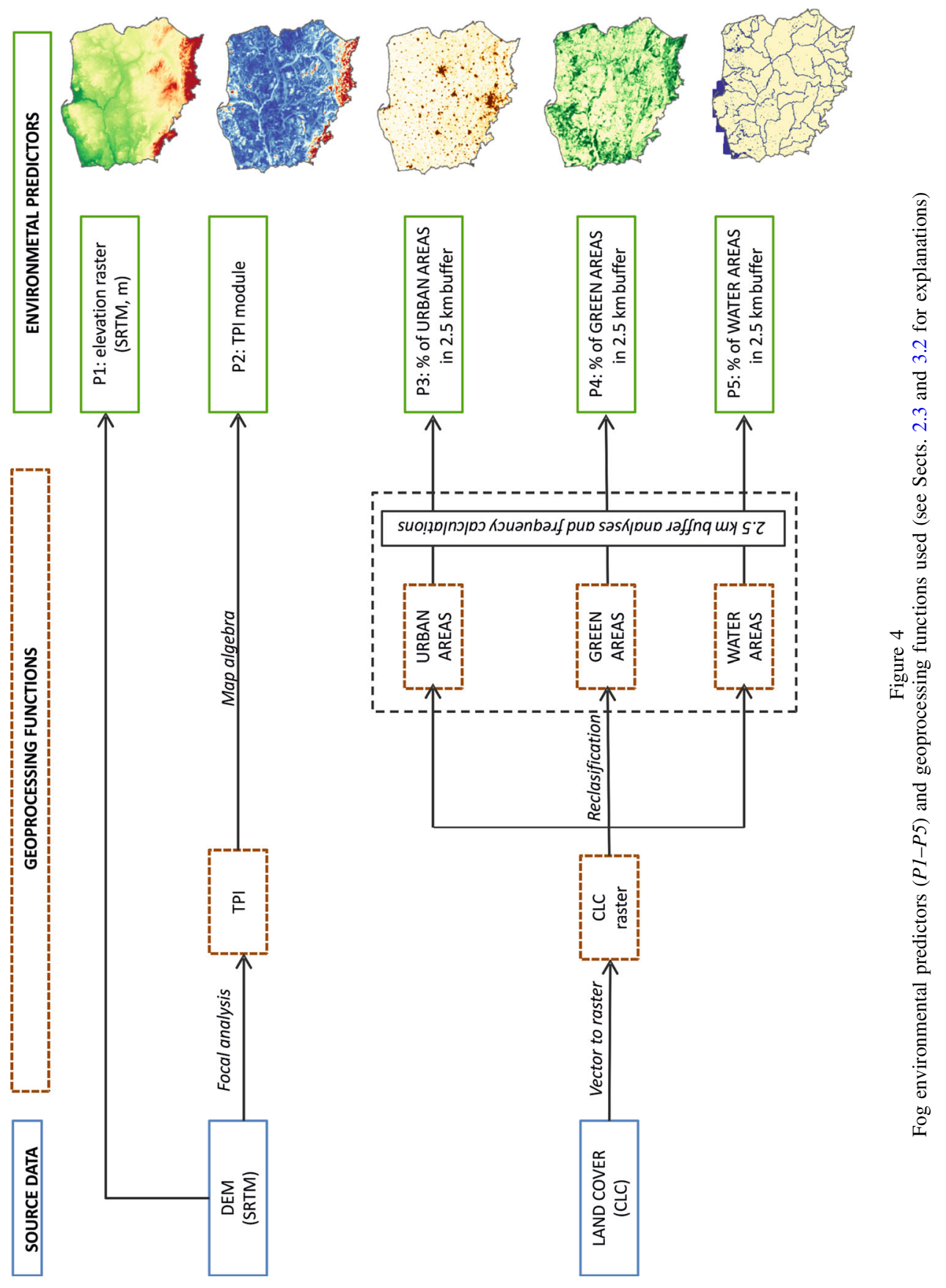


Table 2

Reclassified and aggregated CLC Classes

\begin{tabular}{|c|c|}
\hline New aggregated class & Original CLC class \\
\hline \multirow[t]{3}{*}{ Urban areas } & 1.1 Urban fabric \\
\hline & $\begin{array}{l}1.2 \text { Industrial, commercial and transport } \\
\text { units }\end{array}$ \\
\hline & 1.3 Mine, dump and construction sites \\
\hline \multirow[t]{6}{*}{ Green areas } & $\begin{array}{l}\text { 1.4 Artificial, non-agricultural vegetated } \\
\text { areas }\end{array}$ \\
\hline & 2.2 Permanent crops \\
\hline & 2.3 Pastures \\
\hline & 2.4 Heterogeneous agricultural areas \\
\hline & 3.1 Forests \\
\hline & 3.2 Scrub and/or herbaceous vegetation \\
\hline \multirow{2}{*}{$\begin{array}{l}\text { Wetlands and water } \\
\text { bodies }\end{array}$} & 4.1 Inland wetlands \\
\hline & 5.1 Inland waters \\
\hline
\end{tabular}

Table 3

Fog environmental predictors chosen for testing

\begin{tabular}{ll} 
Code & Predictor \\
\hline P1 & $\begin{array}{l}\text { Elevation (DEM) } \\
\text { P2 }\end{array}$ \\
Landform (TPI) \\
P3 & $\begin{array}{c}\text { Percentage of urban areas in } 2.5 \mathrm{~km} \text { radius circle buffer } \\
\text { (CLC) }\end{array}$ \\
P4 & $\begin{array}{c}\text { Percentage of green areas in } 2.5 \mathrm{~km} \text { radius circle buffer } \\
\text { (CLC) }\end{array}$ \\
P5 & $\begin{array}{c}\text { Percentage of wetlands and water in } 2.5 \mathrm{~km} \text { radius circle } \\
\text { buffer (CLC) }\end{array}$ \\
P6 & Favourable meteorological conditions (FMC)
\end{tabular}

2004; Hengl 2007, 2009)—SK output raster dataset. The final result (MLRK output raster dataset) was achieved by adding both the MLR raster dataset and the interpolated residuals raster dataset:

$$
\text { MLRK raster }=\text { MLR raster }+ \text { SK raster }
$$

An appropriate FMEC map was then created. The prediction results of both the MLR and the MLRK procedures were cross-validated via a classic leaveone-out approach (GEISSER 1975; IsAAKS and SRIVASTAVA 1989). Error statistics including: mean error (ME), mean absolute error (MAE) and root mean square error (RMSE) were calculated to evaluate the obtained results (summarized in Table 4 after Li and HEAP 2008). Their use in spatial interpolation and interpretation is widely known and well described (e.g. Willmott and Matsuura 2006; Szymanowski et al. 2012).
Table 4

Error metrics used in FMEC model validation

\begin{tabular}{lll}
\hline Symbol & Error metrics & Mathematical Expression \\
\hline ME & Mean error & $\frac{1}{N} \sum_{i}\left(M_{i}-O_{i}\right)$ \\
MAE & Mean absolute error & $\frac{1}{N} \sum_{i}\left|M_{i}-O_{i}\right|$ \\
RMSE & Root mean square error & $\sqrt{\frac{1}{N}} \sum_{i}\left(M_{i}-O_{i}\right)^{2}$ \\
\hline
\end{tabular}

$N$ total number of pairs, $M_{i}$ modelled fog frequency (days with fog favourable conditions), $O_{i}$ observed fog day frequency

\section{Results}

\subsection{Favourable meteorological conditions ( $f m c)$ maps}

Predictive modelling based on FMC algorithms applied to RegCM gridded data was used to identify favourable conditions for selected weather phenomena (see Sect. 3.1 for details). FMC maps (Fig. 5) show spatially continuous probability of a day with favourable conditions for the occurrence of certain weather phenomena during the whole year. In other words, FMC maps show regional variability of weather conditions favouring the occurrence of phenomena such as thunderstorms, glaze, rime, and fog.

Validation of RegCM modelling itself was done through the calculation of FMC algorithms using available in situ data (Table 5). For thundersotrms, glaze and rime RegCM FMC calculation resulted as very similar to in situ FMC calculation with mean bias smaller than $1.5 \%$. In case of the fog FMC map RegCM results were strongly underestimated.

FMC maps do not correspond exactly with observational data, as they present the probability of the occurrence of favourable conditions, which is not the same as the observed frequency of weather phenomena. Local variability of atmospheric phenomena makes FMC maps quite difficult to subject to any form of objective verification and validation of modelling results against actual observations. One weather station is often not representative of a particular climate region at mesoscale level (3-100 km). Standardized WMO instructions indicate typical location characteristics but it is not easy to confirm them, especially due to weather station 
exposure (World Meteorological Organization 2008). Of the created maps, only the thunderstorms frequency map can be interpreted as highly representative on a regional scale, which can be clearly seen from the results of correlation analysis between FMC maps and weather station data (Table 6). Thunderstorms FMC probability was found to be very strongly correlated
(Pearson's coefficient $r>0.8$, at significance level $p<0.001$ ) with the frequency of thunderstorm observations calculated via in situ data. Despite the occurrence of thunderstorms over a rather limited geographic area at a particular time of day, they usually are associated with convective processes arising within unstable air masses or frontal systems.
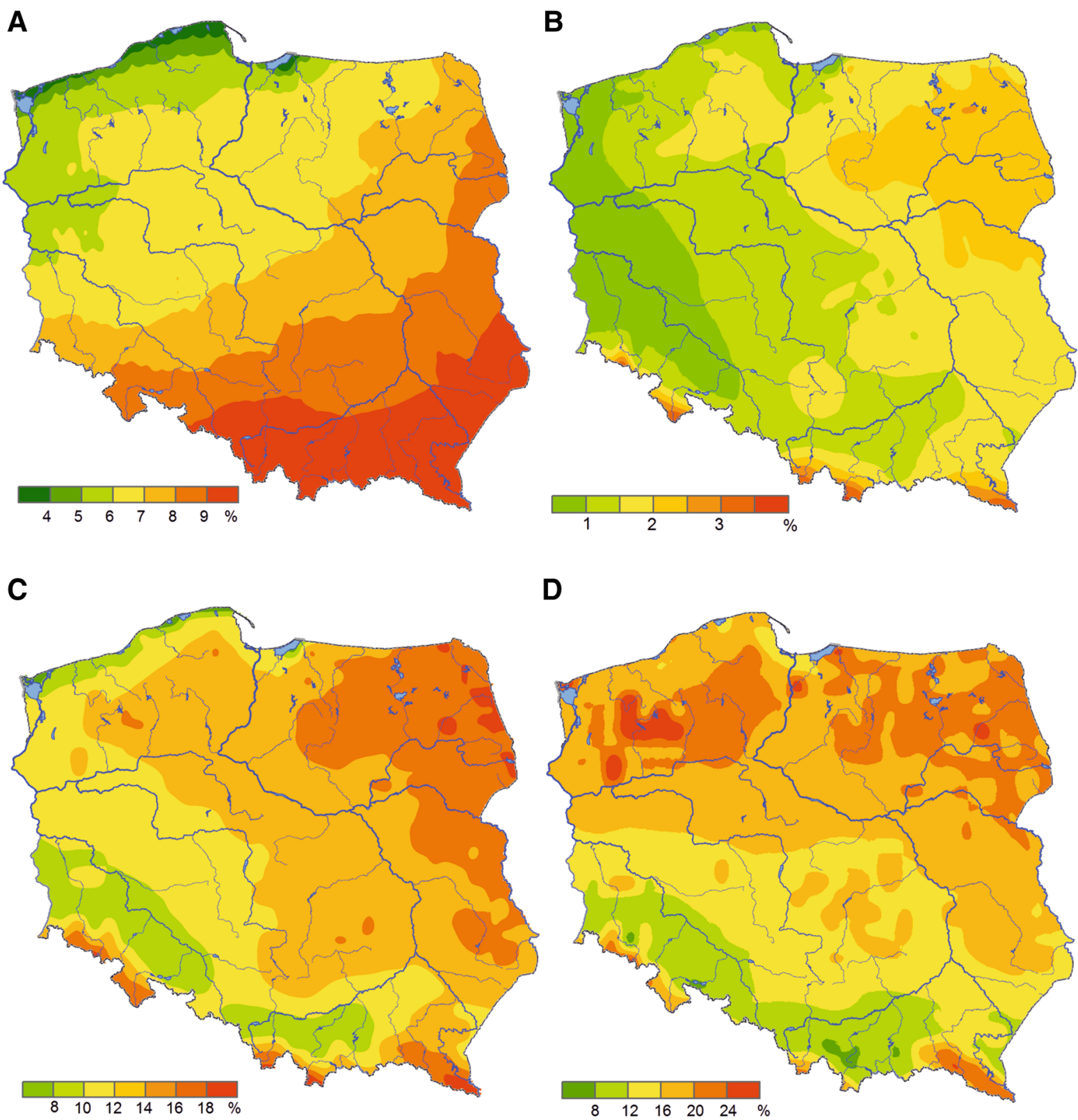

Figure 5

Average annual probability (\%) of a day with thunderstorms (a), glaze (b), rime (c) and fog (d) favourable conditions occurrence. FMC maps 
Table 5

Validation of RegCM FMC results against FMC calculated from available in situ data

\begin{tabular}{|c|c|c|c|c|c|c|}
\hline Modelled phenomenon & $\begin{array}{l}\text { Number of } \\
\text { stations/grid points }\end{array}$ & Validation period & $\begin{array}{l}\text { RegCM } \\
\text { FMC } \\
\text { Mean }\end{array}$ & $\begin{array}{l}\text { Observations FMC } \\
\text { Mean }\end{array}$ & $\begin{array}{l}\text { RegCM } \\
\text { Mean Bias }\end{array}$ & $\begin{array}{l}\text { RegCM } \\
\text { Bias Std }\end{array}$ \\
\hline Thunderstorms & 3 & 2003-2010 & 5.0 & 5.1 & -0.1 & 1.4 \\
\hline Glaze & 3 & $2003-2010$ & 1.3 & 1.5 & -0.2 & 0.2 \\
\hline Rime & 42 & $1966-2010$ & 20.8 & 19.4 & 1.4 & 5.7 \\
\hline Fog & 42 & $1966-010$ & 6.2 & 19.8 & -13.7 & 8.2 \\
\hline
\end{tabular}

Explanations: FMC MEAN, mean annual probability (\%) of a day with a given phenomenon favourable conditions occurrence averaged for all stations/grid points used in the validation process ( RegCm FMC MEAN-calculated from RegCM data, Observations FMC MEANcalculated from in situ data); RegCM MEAN BIAS, average difference between RegCM FMC result and observation FMC result; RegCM BIAS STD, standard deviation of calculated biases among all stations/grid points

Table 6

Correlation analysis between FMC results and phenomena observations $(n=61)$

\begin{tabular}{llll}
\hline $\begin{array}{l}\text { Modelled } \\
\text { phenomenon }\end{array}$ & $\begin{array}{l}\text { Pearson's } \\
\text { coefficient } \\
(r)\end{array}$ & $\begin{array}{l}\text { Coefficient of } \\
\text { determination } \\
\left(R^{2}\right)\end{array}$ & $\begin{array}{l}\text { Correlation } \\
\text { significance } \\
(p)\end{array}$ \\
\hline Thunderstorms & 0.84 & 0.71 & $<0.001$ \\
Glaze & 0.60 & 0.36 & $<0.001$ \\
Rime & 0.39 & 0.15 & 0.002 \\
Fog & 0.15 & 0.02 & 0.253 \\
\hline
\end{tabular}

In such situations the overall annual frequency of observations may be related to the whole region. In addition, the probability of glaze FMC is relatively strongly $(r>0.6, p<0.001)$ correlated with observations. The occurrence of glaze is induced by freezing precipitation: hence it can be considered regionally dependent as well. Nevertheless, detailed regional variability remains beyond the spatial resolution of modelled maps.

Statistical relationship between probabilities of rime and fog FMC and observations are low ( $r=0.39$ for rime) and weak $(r=0.15$ for fog), correspondingly. Rime is in fact, a form of frozen fog caused mostly by the same environmental factors that affect the occurrence of fog. However, the meteorological conditions favouring the deposition of rime are slightly easier to recognize (АнTI and MAKKONEN 1982) and are also easier to predict. Rime occurrence is also limited to the cold season (in Poland from October to April), whereas fog may appear yearround in Poland and is strongly affected by local environmental conditions. This means some of the very local fog occurrences might not be identified due
Table 7

Summary of variables significance

\begin{tabular}{lccc}
\hline Variable & Significant $(\%)$ & Negative $(\%)$ & Positive (\%) \\
\hline P1 & 71.9 & 0.0 & 100.0 \\
P2 & 100.0 & 0.0 & 100.0 \\
P3 & 75.0 & 100.0 & 0.0 \\
P4 & 65.6 & 0.0 & 100.0 \\
P5 & 6.3 & 62.5 & 37.5 \\
P6 & 75.0 & 0.0 & 100.0 \\
\hline
\end{tabular}

to the relatively coarse spatial resolution of RegCM data. The fog FMC map was found to be in agreement with the satellite-based map of fog and low stratus frequency created by CERMAK et al. (2009) at comparable spatial resolution to that of the RegCM data but FMC frequency values were underestimated.

\subsection{Favourable Meteorological and Environmental Conditions (FMEC) MAP: Fog Example}

Statistical significance of additional fog predictors was examined through the stepwise regression analysis. The results were summarized in Table 7 . Five out of six explanatory variables turned out to be statistically significant for most of the iterations and showed a consistent and stable relationship with the dependent variable. Predictors P1 (elevation), P2 (landform), P4 (\% of green areas), and P6 (favourable meteorological conditions) were positively correlated with the dependent variable in $100 \%$ of iterations and P3 (\% of urban areas) was negatively correlated, which came into agreement with the initial assumptions made for this study. The predictor P5 (\% of 
Table 8

Stepwise regression analysis results

\begin{tabular}{|c|c|c|c|c|c|c|c|c|c|c|c|}
\hline Step & AdjR2 & $\mathrm{AICc}$ & $\mathrm{JB}$ & $\mathrm{K}(\mathrm{BP})$ & MaxVIF & SA & Cov1 & Cov2 & Cov3 & Cov4 & Cov5 \\
\hline 1 & 0.84 & 369.99 & 0.30 & 0.16 & 1.00 & 0.10 & $+\mathrm{P} 2$ *** & & & & \\
\hline 1 & 0.76 & 394.51 & 0.00 & 0.00 & 1.00 & 0.00 & $+\mathrm{P} 1 * * *$ & & & & \\
\hline 2 & 0.87 & 359.87 & 0.46 & 0.26 & 1.00 & 0.07 & $+\mathrm{P} 2 * * *$ & $+\mathrm{P} 6 * * *$ & & & \\
\hline 2 & 0.85 & 366.44 & 0.23 & 0.39 & 1.02 & 0.13 & $+\mathrm{P} 4 * *$ & $+\mathrm{P} 2 * * *$ & & & \\
\hline 3 & 0.89 & 351.43 & 0.00 & 0.01 & 5.10 & 0.01 & $+\mathrm{P} 2 * * *$ & $+\mathrm{P} 6 * * *$ & $+\mathrm{P} 1$ & & \\
\hline 3 & 0.88 & 357.37 & 0.57 & 0.69 & 1.03 & 0.11 & $+\mathrm{P} 4 * *$ & $+\mathrm{P} 2 * * *$ & $+\mathrm{P} 6 * * *$ & & \\
\hline 3 & 0.87 & 360.44 & 0.46 & 0.54 & 1.15 & 0.04 & $-\mathrm{P} 3$ & $+\mathrm{P} 2 * * *$ & $+\mathrm{P} 6 * * *$ & & \\
\hline 3 & 0.88 & 357.37 & 0.57 & 0.69 & 1.03 & 0.11 & $+\mathrm{P} 4 * *$ & $+\mathrm{P} 2 * * *$ & $+\mathrm{P} 6^{* * *}$ & & \\
\hline 3 & 0.86 & 363.21 & 0.57 & 0.45 & 1.07 & 0.12 & $+\mathrm{P} 4 * *$ & $-\mathrm{P} 3 * *$ & $+\mathrm{P} 2 * * *$ & & \\
\hline 4 & 0.89 & 351.44 & 0.00 & 0.03 & 5.44 & 0.02 & $+\mathrm{P} 4 *$ & $+\mathrm{P} 2 * * *$ & $+\mathrm{P} 6$ *** & $+\mathrm{P} 1$ & \\
\hline 4 & 0.89 & 351.77 & 0.00 & 0.06 & 5.12 & 0.01 & $-\mathrm{P} 3$ & $+\mathrm{P} 2 * * *$ & $+\mathrm{P} 6^{* * *}$ & $+\mathrm{P} 1$ & \\
\hline 4 & 0.88 & 357.38 & 0.45 & 0.97 & 1.16 & 0.07 & $+\mathrm{P} 4 * *$ & $-\mathrm{P} 3$ & $+\mathrm{P} 2 * * *$ & $+\mathrm{P} 6 * * *$ & \\
\hline 5 & 0.89 & 351.40 & 0.00 & 0.11 & 5.45 & 0.01 & $+\mathrm{P} 4$ & $-\mathrm{P} 3$ & $+\mathrm{P} 2 * * *$ & $+\mathrm{P} 6 * * *$ & $+\mathrm{P} 1 * * *$ \\
\hline
\end{tabular}

Explanations: $\mathrm{AdjR}^{2}$, AICc, JB, K(BP), MaxVIF and SA-abbreviations explained in part 3.2

Cov1, Cov2, Cov3, Cov4, Cov5-regression model covariates

$* 0.10, * * 0.05, * * * 0.01$-model variable significance

water/wetlands) resulted as insignificant and was excluded from the analysis-it seems that the water and wetlands identified within the buffer zones around weather stations seemed not to be sufficiently representative for the purpose of analysis.

The final MLR model was determined taking into account both the stepwise regression results (Table 8) and knowledge-based experience. The most complex model with five covariates (P1, P2, P3, P4 and P6) was selected. The model explained $89 \%$ of variation in annual foggy day frequency $\left(\operatorname{adj} R^{2}=0.89\right)$. The corrected Akaike information criterion (AICc) was found to be the smallest for the selected model, which also show that it is relatively well-fitted. Maximum (from all VIF values checked for every environmental variable) VIF factor was also acceptable $(<7.5)$; in effect, there is no redundancy (multicollinearity) among the model's explanatory variables. The Koenker Statistic p-value test resulted in a not statistically significant value $[\mathrm{K}(\mathrm{BP})>0.05]$, hence, the relationships modelled are consistent. Although covariates P3 and $\mathrm{P} 4$ in the selected regression model were not statistically significant at $p<0.1$, it was decided to use them anyway because of their proven influence on fog occurrence (e.g. SACHweH and KoEPKE 1997; JACOBS et al. 2007), and overall high significance in the stepwise regression analysis (Table 8).

While geographically weighted regression (GWR) (BRUNSDON et al. 1996; Fotheringham et al. 1998,
2002) may seem to be more suitable for capturing local variability, it could not be used with reliable results in this study. First of all, the performed Koenker Test did not indicate a spatial nonstationarity which should characterised the GWR input data (BRUNSDON et al. 1996; GAO and Li 2011). Moreover, number of observation points is regarded as insufficient for sensible GWR calibration. It is suggested that at least 150 data points should be employed in the analysis to build reliable local regressions models and capture local (not regional or global) trends (Fotheringham 2010). There are also a few weather stations in the East Poland which are spatially isolated by large areas over which no data are recorded. It could produce excessive bias in local estimation.

JB test indicated that regression residuals are not normally distributed and the model may need additional geostatistical modelling performed on its residals. Global Moran's I test was performed (Table 9), as SA statistics $(\mathrm{SA}=0.01$ ) had shown spatial autocorrelation among regression residuals. Given a z-score of 2.02, there is a less than $5 \%$ likelihood $(p=0.043)$ that the clustered pattern could be the result of random events and spatial autocorrelation is statistically significant.

Due to the positive result of the spatial autocorrelation test performed on regression residuals, Simple Kriging with normal score transformation 
Table 9

Global Moran's I test summary

\begin{tabular}{lr}
\hline Moran's I statistic parameter & \multicolumn{1}{c}{ Value } \\
\hline Moran's index & 0.194 \\
Expected index & -0.017 \\
Variance & 0.011 \\
z-score & 2.018 \\
$p$ value & 0.043 \\
\hline
\end{tabular}

was employed for their interpolation. Figure 6 shows the output fog FMEC probability map generated through a combination of a deterministic regression part and residual interpolation (MLRK method).
Cross-validation resulted in satisfying values of error statistics which were improved for the MLRK model (Table 10) compared to results achieved with the deterministic part (MLR) alone. Both the validation results and visual evaluation make it possible to regard the final FMEC map as valuable and representative on the scale of Poland. It reflects both the general trends presented in the Climatic atlas of Poland (LoRENC 2005) and detailed information on environmental variability. Moreover, the FMEC map was found to be in substantial accordance with some high resolution $(1 \mathrm{~km})$ remote sensing derivative products presenting the fog frequency (Musial et al. 2014).

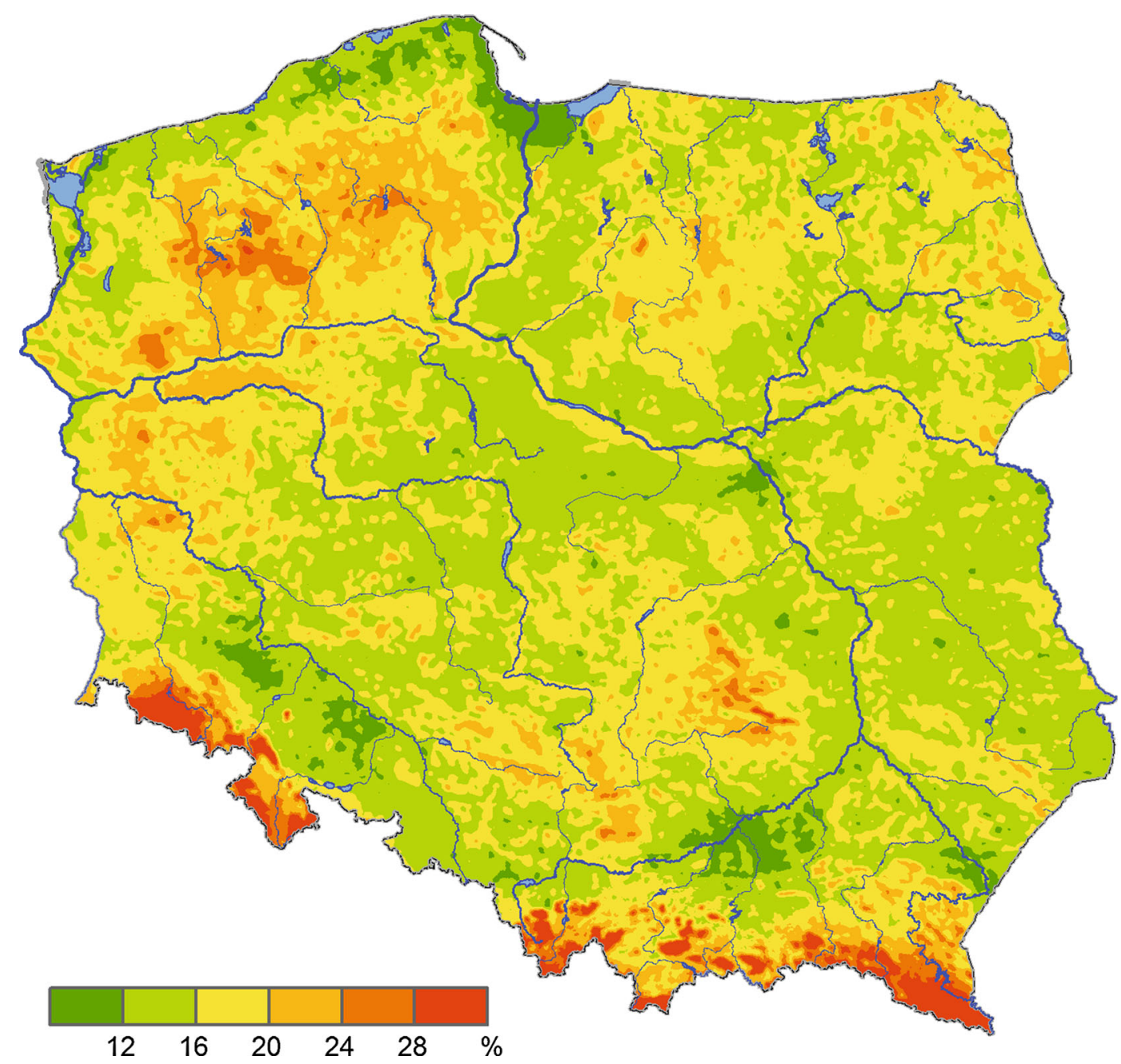

Figure 6

Average annual probability (\%) of day with fog occurrence. FMEC map 
Table 10

Cross-validation results

\begin{tabular}{llll}
\hline & ME & MAE & RMSE \\
\hline MLR & 0.000 & 2.839 & 3.954 \\
MLRK & 0.100 & 1.168 & 1.604 \\
\hline
\end{tabular}

\section{Conclusions}

This study describes climate mapping techniques used for spatially discontinuous atmospheric phenomena. Thunderstorms, glaze, rime and fog were selected to test some of the existing methods and develop a predictive modelling approach for mapping location-dependent phenomena. Climatological maps based on a 45-year analysis (1966-2010) were created for Poland in order to identify distinct regions with a higher frequency and intensity of selected weather hazards. In case of hugely location dependent phenomena, observational data obtained from only 61 weather stations are definitely not sufficient for spatial interpolation over the entire territory of Poland. The number of data points is extremely important for spatial interpolation-the more data available, the better-but the complex nature of atmospheric phenomena makes interpolation even more difficult unless additional, environmental factors are also taken into account.

This study introduces quite an innovative method of using predictive modelling for climatological analysis of atmospheric phenomena over Poland. The presented approach remains valid for every relatively large area where orography and land cover are not homogeneous. The method proposed in this study uses a Regional Climate Model to yield regularly distributed gridded data and to assimilate them into algorithms describing favourable meteorological conditions for each given weather phenomenon. The algorithms have been previously validated on both observational and modelled weather data (WYPYCH et al. 2014; UstRnUl et al. 2015). The resulting FMC maps exhibit an adequate quality of prediction. Both quantitative validation and visual knowledge-based interpretation have confirmed a good estimation of the spatial distribution of selected phenomena over the entire territory of Poland. The maps show general patterns and relationships (LORENC 2005) and allow to avoid wrong estimation which can occur during traditional interpolation of strongly local data from observations. As FMC maps were designed as regional, they are determined by the resolution of the input data (RegCM grid-20 km). For this reason, it is not possible to identify local differences in the maps, which should rather be considered as moderately generalized-but still valuable for regional analysis. The thunderstorm frequency FMC map is considered to be the most accurate map with very strong correlation with observational data $(r=0.84)$. The annual glaze and rime frequency FMC maps are also representative for the country area-considering the complexity of factors affecting these phenomena. Only the fog frequency FCM map proved to be strongly underestimated for southern Poland, as it does favour less heterogeneous areas in terms of orography and land cover.

Consequently, an additional fog frequency FMEC map was created with the use of multiple linear regression kriging (MLRK). Environmental correlation was based on several relevant predictors derived from elevation model and land-cover data-together with a previously obtained FMC map. The final map was found to be more accurate for analyzing the spatial patterns on a regional scale.

Although the generated maps cover just the area of Poland, the methodological background presented in this paper may be considered broadly applicable. An appropriate approach to geospatial predictive modelling should be preceded by detailed analysis of physical processes behind the analysed atmospheric phenomena. An extended exploration of key environmental factors affecting the modelled variable should be performed in order to recognise predictors, which may help to explain properly its spatial variability. The proper selection of predictors must avoid underestimation of the model, but also redundancy among proposed variables.

The modelling approach is characterised by some uncertainties, which one should be aware of in the analytical process. Some of these uncertainties can be at least partially eliminated. First, algorithms designed for favourable meteorological conditions may be improved by employing additional parameters or changing coefficients. Second, modelled data 
(RegCM in this study) are often biased because of certain model assumptions, so an improvement can be made in the model's physical and topographical parameters' configuration and downscaling techniques.

In this study, linear regression was used as a deterministic element of a spatial interpolation procedure which may cause some simplification in the final outcome. Although the results were found to be satisfactory, additional methods including nonlinear models (VICENTE-SERRANO et al. 2010) or artificial neural networks should be tested in the future to verify the possibility of further improvements. Among new and very powerful, spatially continuous environmental datasets which may be used as predictors for this type of analysis, satellite data seem to be invaluable and are increasingly being used for climatological analysis of fog (e.g. Bendix 2002; Cermak et al. 2009; Musial et al. 2014; Avotniece et al. 2015). The importance of climate maps based on remotely sensed data is even greater because of potential use for validation of modelling results in case of limited data from weather observations. Lightning detection and weather radar imagery complemented by conventional meteorological measurements offer opportunities for the validation of predictions of thunderstorms as well as freezing rain.

In addition to the limitations already mentioned, geospatial predictive modelling based on physical relationships between meteorological and environmental parameters favouring the occurrence of a particular atmospheric phenomenon possesses great potential for climate mapping and weather forecasting. Algorithms used to create maps in this study will be also incorporated into an operational numerical weather model.

\section{Acknowledgments}

This work was performed as a part of the ISOK project (IT system for country protection against extreme hazards; POIG.07.01.00-00-025/09) which was co-financed by the European Fund of Regional Development under the Operational Programme Innovative Economy and the Polish Government.
Authors would like to thank Łukasz Harasimowicz, Rafał Kielar, Tomasz Knopik, Szymon Pysz and Witold Wiążewski from the Institute of Meteorology and Water Management-National Research Institute whose previous work on fog, glaze, rime and thunderstorm detection algorithms in the project has contributed to this article. The authors would like to also thank the anonymous reviewers for their helpful comments and remarks.

Open Access This article is distributed under the terms of the Creative Commons Attribution 4.0 International License (http:// creativecommons.org/licenses/by/4.0/), which permits unrestricted use, distribution, and reproduction in any medium, provided you give appropriate credit to the original author(s) and the source, provide a link to the Creative Commons license, and indicate if changes were made.

\section{REFERENCES}

Ahti, K., and Makkonen, L. (1982), Observations on rime formation in relation to routinely measured meteorological parameters, Geophysica 19, 75-85.

Avotniece, Z., Klavins, M., and Lizuma, L. (2015), A Fog climatology in Latvia, Theor. Appl. Climatol 122(1), 97-109.

Benavides, R., Montes, F., Rubio, A., and Osoro, K. (2007), Geostatistical modelling of air temperature in a mountainous region of Northern Spain, Agr. Forest Meteorol. 146, 173-188.

Bendix, J. (2002), A satellite-based climatology of fog and lowlevel stratus in Germany and adjacent areas, Atmos. Res. 64, 3-18.

Berry, J.K., Predictive Modeling, In Analyzing Geo-Spatial Resource Data-A hands-on case study in spatial analysis and data mining (ed. Berry J.K.) (W.M. Keck Scholar in Geosciences, University of Denver, Denver, Colorado 2005) chapter 13, pp 13.1-13.12.

Blanchet, J., and Lehning, M. (2010), Mapping snow depth return levels: smooth spatial modeling versus station interpolation, Hydrol. Earth Syst. Sci. 14, 2527-2544.

Bossard, M., Feranec, J., and Otahel, J. (2000), CORINE land cover technical guide-Addendum 2000, http://www.eea.europa. eu, accessed in Jan. 2015.

Brown, D.P., and Comrie, A.C. (2002), Spatial modeling of winter temperature and precipitation in Arizona and New Mexico, USA, Clim. Res. 22, 115-128.

Brunsdon, C., Fotheringham, A. S., and Charlton, M. E. (1996), Geographically Weighted Regression: A Method for Exploring Spatial Nonstationarity, Geographical Analysis 28, 281-298. doi:10.1111/j.1538-4632.1996.tb00936.x.

Cermak, J., Eastman, R.M., Bendix, J., and Warren, S.G. (2009), European climatology of fog and low stratus based on geostationary satellite observations, Q. J. R. Meteorol. Soc. 135, 2125-2130.

Chapman, L., and Thornes, J.E. (2003), The use of geographical information systems in climatology and meteorology Prog. Phys. Geogr. 27(3), 313-330. 
Diem, J.E., and Comrie, A.C (2002), Predictive mapping of air pollution involving sparse spatial observations, Eniron. Pollution 119, 99-117.

Di Piazza, A, Lo Conti, F., Noto, L.V., Viola, F., and La Loggia, G. (2011), Comparative analysis of different techniques for spatial interpolation of rainfall data to create a serially complete monthly time series of precipitation for Sicily, Italy, Int. J. Appl. Earth Obs. Geoinf. 13, 396-408.

Dobesch, H., Dumolard, P., and Dyras, I. (eds.), Spatial Interpolation for Climate Data : the Use of GIS in Climatology and Meteorology (ISTE, London 2007).

Elguindi, N., Bi, X., Giorgi, F., Nagarajan, B., Pal, J., Solmon, F., Rauscher, S., Zakey, A., and Giuliani, G. (2011), Climatic Model RegCM User Manual-Version 4.1. Trieste, Italy.

Fotheringham, A.S., Brunsdon, C., and Charlton, M.E. (1998), Geographically weighted regression: a natural evolution of the expansion method for spatial data analysis, Environment and Planning A, 30(11), 1905-1927.

Fotheringham, A. S., Brunsdon, C., and Charlton, M. (2002), Geographically weighted regression: the analysis of spatially varying relationships, Wiley, ss. 282.

FotheringhAM, A. S. (2010), Geographically weighted regression. In: Warf, B. (Ed.), Encyclopedia of geography, SAGE Publications, Thousand Oaks, 1225-1232.

FrankLIN, J. (1995), Predictive vegetation mapping: geographic modelling of biospatial patterns in relation to environmental gradients, Prog. Phys. Geogr. 19(4), 474-499, doi:10.1177/ 030913339501900403.

Gallant, J.C., and Wilson, J.P. (2000), Primary topographic attributes. In: Wilson, J.P., Gallant, J.C. (Eds.), Terrain Analysis: Principles and Applications, Wiley, New York, 51-85.

GAO, J., and LI, S. (2011), Detecting spatially non-stationary and scale-dependent relationships between urban landscape fragmentation and related factors using Geographically Weighted Regression, Applied Geography 31 (1), 292-302.

GEISSER, S. (1975), The predictive sample reuse method with applications, J. Amer. Statist. Assoc. 70, 320-328.

Giorgi, F., and Anyah, R.O. (2012), The road towards RegCM4, Clim Res 52, 3-6.

HartKamp, A.D., De Beurs, K., Stein, A., and White, J.W., Interpolation techniques for climate variables, NRG-GIS Series 99-01 (CIMMYT, Mexico D.F., 1999).

Hengl, T. (2007), A practical guide to geostatistical mapping of environmental variables. EUR 22904 EN. Office for Official Publications of the European Communities, Luxembourg.

Hengl, T. (2009), A practical guide to geostatistical mapping, 2nd ed. Amsterdam: University of Amsterdam.

Hengl, T., Heuvelink, G.B.M., and Stein, A. (2004), A generic framework for spatial prediction of soil variables based on regression-kriging, Geoderma 120 (1-2), 75-93.

Heuvelink, G.B.M., and Griffith, D.A. (2010), Space-Time Geostatistics for Geography: A Case Study of Radiation Monitoring Across Parts of Germany, Geogr. Anal. 42, 161-179.

Isaaks, E.H., and Srivastava, R.M. (1989), An introduction to applied geostatistics, Oxford Univ. Press, New York.

Jacobs, W., Nietosvaara, V., Bott, A., Bendix, J., Cermak, J., Silas, M., and GultePe, I. (2007), Short range forecasting methods of fog visibility and low clouds, Earth System Science and Environmental Management Final Rep. on COST-722 Action.
Jarvis, A., Reuter, H.I., Nelson, A., and Guevara, E. (2008), Hole-filled SRTM for the globe Version 4, available on-line from the CGIAR-CSI SRTM: http://srtm.csi.cgiar.org, accessed in Jan. 2015.

Jenness, J. (2006), Topographic Position Index (tpi_jen.avx) extension for ArcView 3.x, v. 1.3a., Jenness Enterprises, available on-line: http://www.jennessent.com/arcview/tpi.htm, accessed in Jan. 2015.

Kalnay, E., Kanamitsu, M., Kistler, R., Collins, W., Deaven, D., Gandin, L., Iredell, M., Saha, S., White, G., Woollen, J., Zhu, Y., Chelliah, M., Ebisuzaki, W., Higgins, W., Janowiak, J., Mo, K.C., Ropelewski, C., Wang, J., LeetmaA, A., Reynolds, R., JENne, R., and Joseph, D. (1996), The NCEP/NCAR 40-year reanalysis project, Bull Amer Meteor Soc 77, 437-470.

Keller, D. L., and Kuchera, E.L. (2004), Model-output post-processor algorithm development with interactive visualization software, Natl. Wea. Dig. 28, 47-53.

Kistler, R., Kalnay, E., Collins, W., Saha, G., White, G., Woollen, J., Chelliah, M., Ebisuzaki, W., Kanamitsu, M., Kousky, V., van den Dool, H., Jenne, R., and Fiorino, M. (2001), The NCEP-NCAR 50-year reanalysis: Monthly means CD-ROM and documentation, Bull Amer Meteor Soc 82, 247-267.

Kryza, M., Szymanowski, M., Migała, K., and Pietras, M. (2010), Spatial information on total solar radiation: Application and evaluation of the r.sun model for the Wedel Jarlsberg Land, Svalbard, Polish Polar Research 31, 17-32.

LI, J., and HEAP, A.D., A review of spatial interpolation methods for environmental scientists, Geoscience Australia Records 23, (Australian Government, Canberra 2008).

López-Moreno, J.I., and Nogués-Bravo, D. (2005), A generalized additive model for modelling the spatial distribution of snowpack in the Spanish Pyrenees, Hydrol. Process 19, 3167-3176.

López-Moreno, J.I., and Nogués Bravo, D. (2006), Interpolating snow depth data: a comparison of methods, Hydrol. Process. 20(10), 2217-232.

López Moreno, J.I., and Vicente-Serrano, S.M. (2007), Mapping snowpack distribution over large areas using GIS and interpolation techniques, Clim. Res. 33, 257-270.

LORENC, A. C. (1986), Analysis methods for numerical weather prediction. Q.J.R. Meteorol. Soc. 112, 1177-1194.

Lorenc, H. (ed.), Climatic atlas of Poland, (Institute of Meteorology and Water Management, Warsaw, 2005) (in Polish).

Martínez-CoB, A. (1996), Multivariate geostatistical analysis of evapotranspiration and precipitation in mountainous terrain, $\mathrm{J}$. Hydrol. 174, 19-35.

Musial, J.P., Hüsler, F., Sütterlin, M., Neuhaus, C., and WunDERLE, S. (2014) Daytime Low Stratiform Cloud Detection on AVHRR Imagery, Remote Sens. 6, 5124-5150.

NinYerola, M., Pons, X., and Roure, J.M. (2000), A methodological approach of climatological modelling of air temperature and precipitation through GIS techniques International Journal of Climatology 20: 1823-1841.

NinYerola, M., Pons, X., and Roure, J.M. (2007), Monthly precipitation mapping of the Iberian Peninsula using spatial interpolation tools implemented in a Geographic Information System. Theoretical and Applied Climatology 89: 195-209.

Ninyerola, M., Pons, X., and Roure, J.M. (2007), Objective air temperature mapping for the Iberian Peninsula using spatial interpolation and GIS. International Journal of Climatology 27: 1231-1242. 
Ruiz-Arias, J.A., Pozo-Vázquez, D., Santos-Alamillos, F.J., Lara-Fanego, and Tovar-Pescador, V. (2011), A topographic geostatistical approach for mapping monthly mean values of daily global solar radiation: A case study in southern Spain, Agr. Forest Meteorol. 151(12), 1812-1822.

SACHwen, M., and KoepKe, P. (1997), Fog dynamics in an urbanized area, Theoretical and Applied Climatology 58(1), 87-93.

Shekhar, S., Zhang, P., and Huang, Y. (2005), Spatial Data Mining [in:] Maimon, O. and Rokach, L. (eds.) The data mining and knowledge discovery handbook, Springer 2005, chapter 39, 833-852.

Shirin Manesh, S.S., Ahani, H., and Rezaeian-Zadeh, M. (2013) ANN-based mapping of monthly reference crop evapotranspiration by using altitude, latitude and longitude data in Fars province, Iran, Environ. Dev. Sustain, doi: 10.1007/s10668-0139465-x.

SLUITER, R., Interpolation methods for climate data. Literature review, KNMI Intern Raport (R\&D Information and Observation Technology, De Bilt 2009).

Szymanowski, M., Kryza, M., and Spallek, W. (2012), Air temperature atlas for Poland: the methodical approach. Rozprawy Naukowe Instytutu Geografii i Rozwoju Regionalnego Uniwersytetu Wrocławskiego 26, Uniwersytet Wrocławski, Wrocław (in Polish, English summary).

Szymanowski, M., KRYZA, M., and SpalleK W. (2013), Regressionbased air temperature spatial prediction models: an example from Poland, Meteoroloische Zeitschrift 22(5), 577-585.

Thorne, J., Boynton, R., Flint, L., Flint, A., and Le, T.N. (2012), Development and Application of Downscaled Hydroclimatic Predictor Variables for Use in Climate Vulnerability and Assessment Studies, California Energy Commission, Publication number: CEC-500-2011-010.

Tveito, O.E., Wegehenkel, M., Van der Wel, F., and Dobesch, H., The Use of Geographic Information Systems in Climatology and Meteorology-Final Report COST Action 719 (Official Publications of the European Communities, Luxembourg 2008).

Ustrnul, Z., and Czenierda, D. (2005), Application of GIS for the development of climatological air temperature maps: an example from Poland, Meteorol. Appl. 12, 43-50.

Ustrnul, Z., Wypych, A., Henek, E., Czekierda, D., Walawender, J., Kubacka, D., Pyrc, R., and CZernecki, B., Meteorological hazard atlas of Poland (Institute of Meteorology and Water Management and ATTYKA, Krakow, 2014).

Ustrnul, Z., Wypych, A., HeneK, E., MAciejewski, M., and BochENEK, B. (2015), Climatologically based warning system against meteorological hazards and weather extremes-the example for Poland, Natural Hazards, doi:10.1007/s11069-015-1673-2.

Vicente-Serrano, S.M., Lanjeri, S., and López-Moreno, J.I. (2007), Comparison of different procedures to map reference evapotranspiration using geographical information systems and regression-based techniques, Int. J. Climatol. 27, 1103-1118.

Vicente-Serrano, S.M., López-Moreno, J.I., Vega-Rodriguez, M.I., Beguería, S., and Cuadrat, J.M. (2010), Comparison of regression techniques for mapping fog frequency: application to the Aragon region (northeast Spain), Int. J. Climatol. 30, 935-945.
Vicente-Serrano, S.M., Saz, M.A., and Cuadrat, J.M. (2003), Comparative analysis of interpolation methods in the middle Ebro valley (Spain): application to annual precipitation and temperature, Clim. Res. 24, 161-180.

Wagner, P.D., Fiener, P., Wilken, F., Kumar, S., and Schneider, K. (2012), Comparison and evaluation of spatial interpolation schemes for daily rainfall in data scarce regions, J. Hydrol. 464-465, 388-400.

Walawender, E., Kielar, R., and Ustrnul, Z. (2015), Use of RegCM gridded dataset for thunderstorm favorable conditions analysis over Poland-climatological approach, Theoretical and Applied Climatology, doi:10.1007/s00704-015-1620-x.

WAng, C., Yue, T., and FAN, Z. (2014), Solar Radiation Climatology Calculation in China, Journal of Resources and Ecology $5(2), 132-138$.

Wilby, R.L., and Wigley, T.M.L. (1997), Downscaling general circulation model output: a review of methods and limitations. Progr in Phys Geogr, 21, 530-548.

Willmott, C.J., and Matsuura, K. (2006), On the use of dimensioned measures of error to evaluate the performance of spatial interpolators, International Journal of GIS 20, 89-102.

World Meteorological Organization (2004), Establish Guidelines for implementation of a demonstration project of severe weather forecasting (proposal), Workshop On Severe and Extreme Events Forecasting (Toulouse, 26-29 October 2004). Available online at: http://www.wmo.int/pages/prog/www/DPS/Meetings/ Wshop-SEEF_Toulouse2004/Doc3-1(1).doc (Accessed on: March 2015).

World Meteorological Organization (2008), Guide to Meteorological Instruments and Methods of Observation, 7th ed., WMO-No. 8.

World Meteorological Organization (2011), Guide to climatological practices, WMO no.100, third edition, Available online at: http://www.wmo.int/pages/prog/wcp/ccl/guide/documents/ WMO_100_en.pdf (Accessed on: March 2015).

Wypych, A., Ustrnul, Z., and Henek, E. (2014), Meteorological Hazards-Visualization System for National Protection Against Extreme Hazards for Poland, Meteorol. Hydrol. and Water Manag. 2(1), 37-42.

Yuan, M.B., Butternfield M., Gahegan M., and Miller H., Geospatial data mining and knowledge discovery, In Research Challenges in Geographic Information Science (eds. McMaster R. and Usery) (John Wiley \& Sons, CRC Press, Boca Raton, FL. 2005), chapter 14 , pp. 365-388.

\section{ONLINE DATA SOURCES}

NCEP Reanalysis data provided by the NOAA/OAR/ESRL PSD, Boulder, Colorado, USA, http://www.esrl.noaa.gov/psd/data/reanalysis/reanalysis.shtml, accessed in March 2015.

EEA Data and Maps, CORINE Land Cover, http://www.eea.europa.eu/data-and-maps, accessed in March 2015. 